\title{
Climate variability in central China over the last 1270 years revealed by high-resolution stalagmite records
}

\author{
Dorte Eide Paulsen, Hong-Chun Li*, Teh-Lung $\mathrm{Ku}$ \\ Department of Earth Sciences, University of Southern California, Los Angeles, CA 90089-0740, USA
}

Received 5 April 2002; accepted 30 September 2002

\begin{abstract}
Oxygen and carbon isotopic variations in the upper section of a stalagmite (SF-1) from Buddha Cave $\left(33^{\circ} 40^{\prime} \mathrm{N} 109^{\circ} 05^{\prime} \mathrm{E}\right)$ dated by ${ }^{230} \mathrm{Th} /{ }^{234} \mathrm{U}{ }^{210} \mathrm{~Pb}$ and lamination counting to a time resolution as fine as $1-3$ years have recorded climate changes in central China for the last 1270 years. The changes include those corresponding to the Medieval Warm Period Little Ice Age and 20th-century warming lending support to the global extent of these events. The isotopic records also show cycles of 33, 22, 11, 9.6, and 7.2 years. The 33-year cycle could well represent the $\sim 35$-year periodicity of climate fluctuations previously recognized in China and Europe. Cycles of 22, 11, and 9.6 years have often been associated with the Sunspot or lunar-orbit variations. The 7.2-year cycle was recently identified also in tree-ring records from an area close to Buddha Cave. These cycles suggest that external forcing (e.g. solar irradiance) may affect the summer monsoon over eastern China. The general consistency between the climate characteristics inferred from the stable isotope records of SF-1 and those from other proxy records underscores the value of stalagmites as recorders of paleoclimate.
\end{abstract}

(C) 2003 Elsevier Science Ltd. All rights reserved.

\section{Introduction}

About $20 \%$ of the world's populations live in eastern China where the climate is strongly affected by the monsoon system. Variations in the monsoon circulation have led to climate extremes in the region causing much economic distress and human sufferings not to mention the great loss of lives (Bryant, 1997). Therefore efforts in reconstructing the climate in the recent past for a better understanding of its future variability in this part of the world take on an added socioeconomic dimension.

Only a few reliable instrumental records on climate extending beyond a century or so exist in China (Bradley, 1999). It is thus incumbent on us to examine closely other paleoclimate archives such as historical documents ice cores tree rings and stalagmite. The calcitic cave deposit of speleothems has the attractive feature of being capable of providing long continuous records of high-resolution and accurate chronology. $\delta^{18} \mathrm{O}$ and $\delta^{13} \mathrm{C}$ of the calcite record climatic signals

\footnotetext{
*Corresponding author. Tel.: +1-213-740-6106; fax: + 1-213-7408801 .

E-mail address: hli@earth.usc.edu (H.-C. Li).
}

(Hendy and Wilson, 1968; Dorale et al., 1992) which can be dated through U-series disequilibrium $\left({ }^{230} \mathrm{Th} /{ }^{234} \mathrm{U}\right.$ ${ }^{210} \mathrm{~Pb}$ ) and growth lamination counting (e.g. Li et al 1989; Baskaran and Iliffe, 1993; Baker et al., 1993; Kaufman et al., 1998). Depending on growth rates of the stalagmites under study fine layer-sampling of the specimens allows their $\delta^{18} \mathrm{O}$ and $\delta^{13} \mathrm{C}$ records to be readily read to a resolution of $50-500$ years (e.g. Denniston et al., 1999; Desmarchelier et al., 2000) if not 3-50 years (e.g. Baker et al., 1998; Holmgren et al., 1995; Lauritzen, 1995; Burns et al., 1998; Hellstrom et al., 1998; McDermott et al., 1999; Repinski et al., 1999). Based on such records $\mathrm{Ku}$ and $\mathrm{Li}$ (1998) and $\mathrm{Li}$ et al. (1998) have reconstructed climate of the recent past near Beijing in northeastern China.

We report here our study on a stalagmite (SF-1) from Buddha Cave $\left(33^{\circ} 40^{\prime} \mathrm{N} 109^{\circ} 05^{\prime} \mathrm{E}\right)$ located at an altitude of $\sim 500 \mathrm{~m}$ on the southern flank of Qin Ling Mountains approximately $80 \mathrm{~km}$ south of Xian in central China (Fig. 1). Careful micro-sampling of growth layers combined with multiple dating techniques enables the reconstruction of a $\delta^{18} \mathrm{O}-\delta^{13} \mathrm{C}$ based paleoclimate record for the last 1270 years. A part of the record has an unprecedented $\sim 1$-year resolution. 


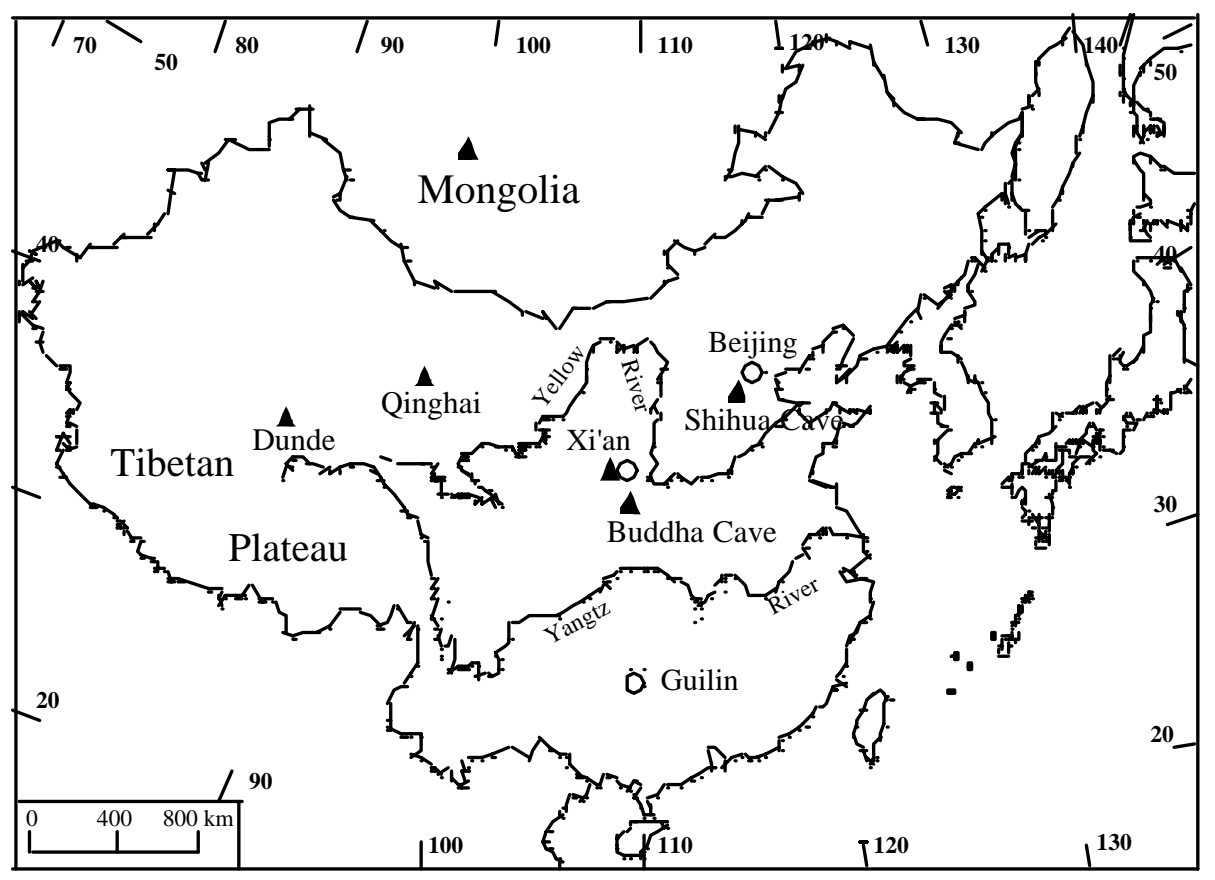

Fig. 1. Map showing the Buddha Cave location in central China and other locations with recent paleoclimate records referred in the text.

The record reveals climate anomalies corresponding to the Medieval Warm Period and Little Ice Age of Europe and the global 20th-century warming trend as well as a number of cyclic variations of different periodicities.

\section{Interpretation of $\delta^{13} \mathrm{C}$ and $\delta^{18} \mathrm{O}$ records}

Mid-to-high latitudinal regions (save desert areas and some coastal regions) exhibit a positive correlation between $\delta^{18} \mathrm{O}$ of precipitation $\left(\delta^{18} \mathrm{O}_{\mathrm{p}}\right)$ and air temperature with $\mathrm{d} \delta{ }^{18} \mathrm{O}_{\mathrm{p}} / \mathrm{d} T$ being generally in the range of $0.5-$ $0.7 \%{ }^{\circ} \mathrm{C}^{-1}$ (Dansgaard, 1964; Rozanski et al., 1993). This temperature coefficient is to be compared with the negative value of about $-0.23 \%{ }^{\circ} \mathrm{C}^{-1}$ for the calcitewater $\delta^{18} \mathrm{O}$ fractionation (Epstein et al., 1953; O’Neil et al., 1969). The difference in magnitude between the two coefficients (i.e. temperature usually has a larger effect on $\delta^{18} \mathrm{O}_{\mathrm{p}}$ than on the water-calcite fractionation) has led to the use of a positive correlation between temperature and $\delta^{18} \mathrm{O}$ of stalagmitic calcite $\left(\delta^{18} \mathrm{O}_{\mathrm{c}}\right)$ for the interpretation of the $\delta^{18} \mathrm{O}_{\mathrm{c}}$ records. Thus heavier $\delta^{18} \mathrm{O}_{\mathrm{c}}$ has been taken to reflect warmer cave temperature or warmer mean annual air temperature outside the cave (Dorale et al., 1992; Gascoyne, 1992; Dorale and Edwards, 1998; $\mathrm{Ku}$ and Li, 1998; Li et al., 1998; McDermott et al., 1999).

The tenability of the approach has been shown in a study of the Shihua Cave in northeastern China (Fig. 1) by $\mathrm{Ku}$ and $\mathrm{Li}$ (1998) and Li et al. (1998) who measured local air temperature and $\delta^{18} \mathrm{O}_{\mathrm{p}}$ as well as $\delta^{18} \mathrm{O}_{\mathrm{c}}$. For the present study of the Buddha Cave we also collected air temperature $\delta^{18} \mathrm{O}_{\mathrm{p}}$ and precipitation amount at weather stations near the cave. It was found that $\mathrm{d} \delta \delta^{18} \mathrm{O}_{\mathrm{p}} /$ $\mathrm{d} T \approx 0.52 \%{ }^{\circ} \mathrm{C}^{-1}$ (Paulsen, 2000) a positive value more than offsetting the negative temperature coefficient for water-calcite fractionation. We further noted that the most intense rainfall had the lowest $\delta^{18} \mathrm{O}_{\mathrm{p}}$ consistent with the rainout effect on $\delta^{18} \mathrm{O}_{\mathrm{p}}$ (Dansgaard, 1964; Rindsberger et al., 1983; Njitchoua et al., 1999). We may therefore assume that a positive correlation between stalagmite $\delta^{18} \mathrm{O}_{\mathrm{c}}$ and surface air temperature exists in the Buddha Cave and that wet years result in the formation of stalagmite layers with lighter $\delta^{18} \mathrm{O}_{\mathrm{c}}$ values. Since yearly changes in precipitation amounts are often much larger than those in air temperature (which seldom exceed $2^{\circ} \mathrm{C}$ ) short-term $\delta^{18} \mathrm{O}_{\mathrm{c}}$ fluctuations in a highresolution $(<10$ years $)$ record would mainly reflect changes in precipitation. Only in coarser (e.g. $>50$ years resolution) records would $\delta^{18} \mathrm{O}_{\mathrm{c}}$ chiefly reflect a change in temperature ( $\mathrm{Ku}$ and $\mathrm{Li}, 1998)$.

The carbon isotopic composition in a speleothem $\left(\delta^{13} \mathrm{C}_{\mathrm{c}}\right)$ reflects that of the soil $p \mathrm{CO}_{2}$ hence that of the vegetation cover above the cave. Climate affects vegetation density with wet and cool conditions in favor of forest development. Plants adapted to a relatively cold/wet climate $\left(\mathrm{C}_{3}\right.$ type $)$ typically have $\delta^{13} \mathrm{C}$ values lighter than those for $\mathrm{C}_{4}$-type plants grown in a warm/ dry climate (-24\%o vs. $-11 \%$ ) (Cerling, 1984; Cerling et al., 1989; Hoefs, 1997). In addition Schleser et al. (1999) showed that under dry and/or warm conditions $\delta^{13} \mathrm{C}$ of $\mathrm{C}_{3}$ plants becomes heavier due to the restricted 
uptake rate of $\mathrm{CO}_{2}$. Apparently enzyme converts almost all of $\mathrm{CO}_{2}$ when the internal $\mathrm{CO}_{2}$ concentration is low suppressing the carboxylation fractionation. In contrast humid and/or cool conditions result in lighter $\delta^{13} \mathrm{C}$ of $\mathrm{C}_{3}$ plants. Therefore changes in vegetation density and $\mathrm{C}_{3} /$ $\mathrm{C}_{4}$ plant ratio will lead to changes in soil $\delta^{13} \mathrm{C}$ which is recorded by the stalagmite with light $\delta^{13} \mathrm{C}$ reflecting wet/ cold climates and heavy $\delta^{13} \mathrm{C}$ dry/warm climates. These general concepts form the basis for interpreting $\delta^{13} \mathrm{C}_{\mathrm{c}}$ in many paleoclimate studies (e.g. Dorale et al., 1992; BarMatthews et al., 1997; Dorale and Edwards, 1998; Ku et al., 1998). We will follow suit in the present study of stalagmite SF-1 bearing in mind that our interpretation does not take into account of the effect of possible dissolution of the limestone host rock on $\delta^{13} \mathrm{C}_{\mathrm{c}}$. The extent of dissolution would depend on changes in dripwater pathways or soil-water residence times above the cave (Baker et al., 1997; Bar-Matthews et al., 1999). (The lack of conspicuous changes in depositional features for the part of SF-1 under study leads us to assume that the drip-water pathway of the cave has remained relatively constant for the last $\sim 2000$ years.)

Based on the above considerations a rule-of-thumb summary can be formulated for the usage of $\delta^{18} \mathrm{O}_{\mathrm{c}}$ and $\delta^{13} \mathrm{C}_{\mathrm{c}}$ signals to qualitatively assess climate variability in terms of "warmer (heavier $\delta^{18} \mathrm{O}_{c}$ )" "colder (lighter $\delta^{18} \mathrm{O}_{\mathrm{c}}$ )" "wetter (lighter $\delta^{13} \mathrm{C}_{\mathrm{c}}$ )" and "drier (heavier $\delta^{13} \mathrm{C}_{\mathrm{c}}$ )" conditions as shown in Tables 1 and 2. Taking into account the time resolution of the stable isotope records aside (e.g. changes in water residence time affect the records on annual scale as opposed to changes in vegetation which operate on decadal or longer scale) the validity of such an interpretation scheme naturally is predicated upon isotopic equilibrium during calcite deposition. Kinetic effects due to rapid degassing of $\mathrm{CO}_{2}$ or evaporation of water from the stalagmiteforming film are commonly negligible in the deep interior of a cave with high relative humidity. Isotopic equilibrium can also be inferred from a comparison of $\delta^{18} \mathrm{O}$ and $\delta^{13} \mathrm{C}$ in newly formed speleothem layers with those in cave water (Bar-Matthews et al., 1996).

An unequivocal way to test equilibrium deposition for $\delta^{18} \mathrm{O}$ would be to obtain similar records in two stalagmites from the same cave. Short of such a reproducibility check we resorted to using the criteria suggested by Hendy (1971) namely relatively constant $\delta^{18} \mathrm{O}_{\mathrm{c}}$ occurs in a single growth layer and no correlation between $\delta^{18} \mathrm{O}_{\mathrm{c}}$ and $\delta^{13} \mathrm{C}_{\mathrm{c}}$ exists in the same layer. Fig. 2a

Table 1

A "rule-of-thumb" summary for the paleoclimate interpretation of $\delta^{13} \mathrm{C}_{\mathrm{c}}$ signals $^{\mathrm{a}}$

\begin{tabular}{lll}
\hline Climate change & $\begin{array}{l}\text { Effect of the climate } \\
\text { change }\end{array}$ & $\begin{array}{l}\text { Isotopic signal } \\
\delta^{13} \mathrm{C}_{\mathrm{c}}\end{array}$ \\
\hline $\begin{array}{l}\text { Drier and/or warmer } \\
\text { climate }\end{array}$ & $\mathrm{C} 3 / \mathrm{C} 4$ plant ratio $\downarrow$ & $\delta^{13} \mathrm{C}_{\mathrm{c}} \downarrow$ \\
& $\begin{array}{l}\delta^{13} \mathrm{C} \text { of } \mathrm{C} 3 \text { plants } \uparrow \\
\text { Vegetation density } \downarrow \\
\text { Water residence time } \uparrow\end{array}$ \\
& $\begin{array}{l}\mathrm{C} 3 / \mathrm{C} 4 \text { plant ratio } \uparrow \\
\text { Wetter and/or colder } \\
\text { climate }\end{array}$ & $\delta^{13} \mathrm{C}_{\mathrm{c}} \downarrow$ \\
& $\begin{array}{l}\delta^{13} \mathrm{C} \text { of C3 plants } \downarrow \\
\text { Vegetation density } \uparrow \\
\text { Water residence time } \downarrow\end{array}$ \\
\hline
\end{tabular}

${ }^{a}$ Vertical arrows indicate the increasing or decreasing trends.

Table 2

A "rule-of-thumb" summary for the paleoclimate interpretation of $\delta^{18} \mathrm{O}_{\mathrm{c}}$ signals ${ }^{\mathrm{a}}$

\begin{tabular}{lll}
\hline Isotopic signal & Resolution & Climatic pattern \\
\hline$\delta^{18} \mathrm{O}_{\mathrm{c}} \uparrow$ & Low $(>50$ years $)$ & Warm \\
& High $(<10$ years $)$ & Dry \\
$\delta^{18} \mathrm{O}_{\mathrm{c}} \downarrow$ & Low $(>50$ years $)$ & Cold \\
& High $(<10$ years $)$ & Wet \\
\hline
\end{tabular}

${ }^{a}$ Vertical arrows indicate the increasing or decreasing trends.

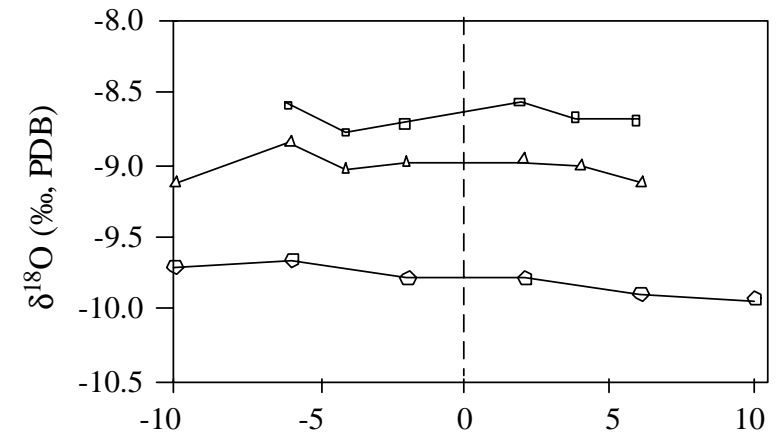

(a)
Distance from central axis $(\mathrm{mm})$

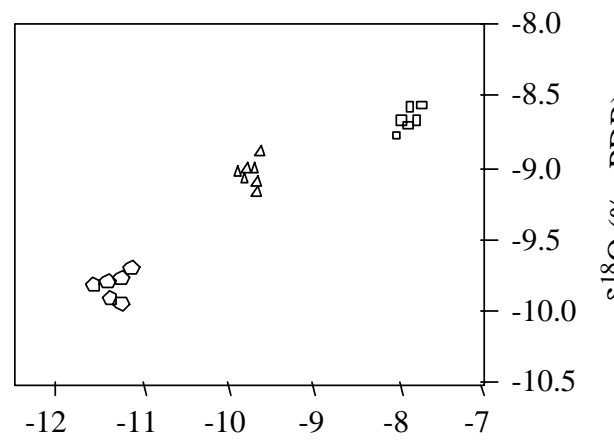

(b)

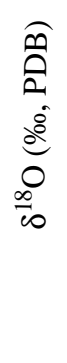

$\delta^{13} \mathrm{C}(\% \circ, \mathrm{PDB})$

Fig. 2. (a) $\delta^{18} \mathrm{O}_{\mathrm{c}}$ distributions in three growth layers of stalagmite SF-1 (b) $\delta^{13} \mathrm{C}_{\mathrm{c}}-\delta^{18} \mathrm{O}_{\mathrm{c}}$ correlations in the three layers. Squares denote data from the layer at $13.5 \mathrm{~mm}$ depth $\left(R^{2}=0.02\right)$; triangles denote data from $23.5 \mathrm{~mm}$ depth $\left(R^{2}=0.60\right)$; and circles denote data from $33.5 \mathrm{~mm}$ depth $\left(R^{2}=0.11\right)$. 
shows the $\delta^{18} \mathrm{O}_{\mathrm{c}}$ values for samples taken from layers at 13.523 .5 and $35.5 \mathrm{~mm}$ on either side of the central growth axis in SF-1. Each of the three layers representing 1-3 annual growth laminae gives fairly constant $\delta^{18} \mathrm{O}_{\mathrm{c}}$ values (Fig. $2 \mathrm{a}$ ). Two of the layers show a very poor correlation $\left(R^{2}=0.02\right.$ and 0.11$)$ between $\delta^{18} \mathrm{O}_{\mathrm{c}}$ and $\delta^{13} \mathrm{C}_{\mathrm{c}}$ (Fig. 2b). The positive test result provides some measure of assurance against gross non-equilibrium isotopic fractionation.

Variations of $\delta^{13} \mathrm{C}_{\mathrm{c}}$ within individual layers are less than $1 \%$ (Fig. 2b) indicating constant or negligible kinetic effect on $\delta^{13} \mathrm{C}_{\mathrm{c}}$ during the calcite deposition. By neglecting $\mathrm{CO}_{2}$ exchange between the drip water and the cave air and other kinetically controlled processes which may influence $\delta^{13} \mathrm{C}_{\mathrm{c}}$ Paulsen (2000) modeled the expected range of $\delta^{13} \mathrm{C}_{\mathrm{c}}$ considering the input of $\mathrm{CO}_{2}$ to groundwater from decomposing organic matter and by limestone dissolution and isotopic equilibrium fractionation between $\mathrm{CO}_{2}(\mathrm{~g})$ and $\mathrm{CaCO}_{3}$. It was found that the average $\delta^{13} \mathrm{C}_{\mathrm{c}}$ value of $-9.8 \%$ (varying from $-6.2 \%$ to $-12 \%$ ) in SF-1 would be consistent with an cave environment characterized by a $\mathrm{C}_{3} / \mathrm{C}_{4}$ plant ratio of 70:30 and a soil/limestone distribution of 75:25 given a calcite- $\mathrm{CO}_{2}(\mathrm{~g})$ fractionation factor of 1.00952 at $15^{\circ} \mathrm{C}$ (Dulinski and Rozanski, 1990) and $\delta^{13} \mathrm{C}$ values of $-27 \%-13 \%$ and $0 \%$ for $\mathrm{C}_{3}$ plants $\mathrm{C}_{4}$ plants and limestone respectively (Cerling, 1984; Hoefs, 1997).

\section{Cave setting and methods}

Specimen SF-1 (Fig. 3) was collected from its growth position in $1996 \sim 200 \mathrm{~m}$ from the cave entrance and $\sim 50 \mathrm{~m}$ below the present land surface. The Buddha Cave is located in an alpine vegetation-covered area with carbonate rocks of middle Ordovician age. A 6-8 m thick Quaternary loess deposit with well-developed soils in its upper 3-5 $\mathrm{m}$ covers the carbonate bedrock. Inside the cave the relative humidity maintains at $98 \%$ and annual temperature at $14 \pm 2^{\circ} \mathrm{C}$. Winter in the area is usually dry. Precipitation mostly comes from summer monsoonal rain between June and September. The transit time for meteoric water through the $50-100 \mathrm{~m}$ thick vadose zone above the cave is relatively short. It has been observed that an increase of drip rates of cave water occurs within about $24 \mathrm{~h}$ after the passing of a rain storm in the area. The cave is situated more than $200 \mathrm{~m}$ above a river bed and high above the local groundwater level. Thus its drip-water comes only from precipitation above the cave the change of which sensitively affect the water residence time in the vadose zone. The study area lies on a lowland with sparse farming and population. Vegetation consists mainly of shrubs and grasses.

Using a computer-controlled high-precision micro miller 478 samples were drilled from upper $3.4 \mathrm{~cm}$ of SF1 with sampling intervals of 50 or $100 \mu \mathrm{m}$. Stable

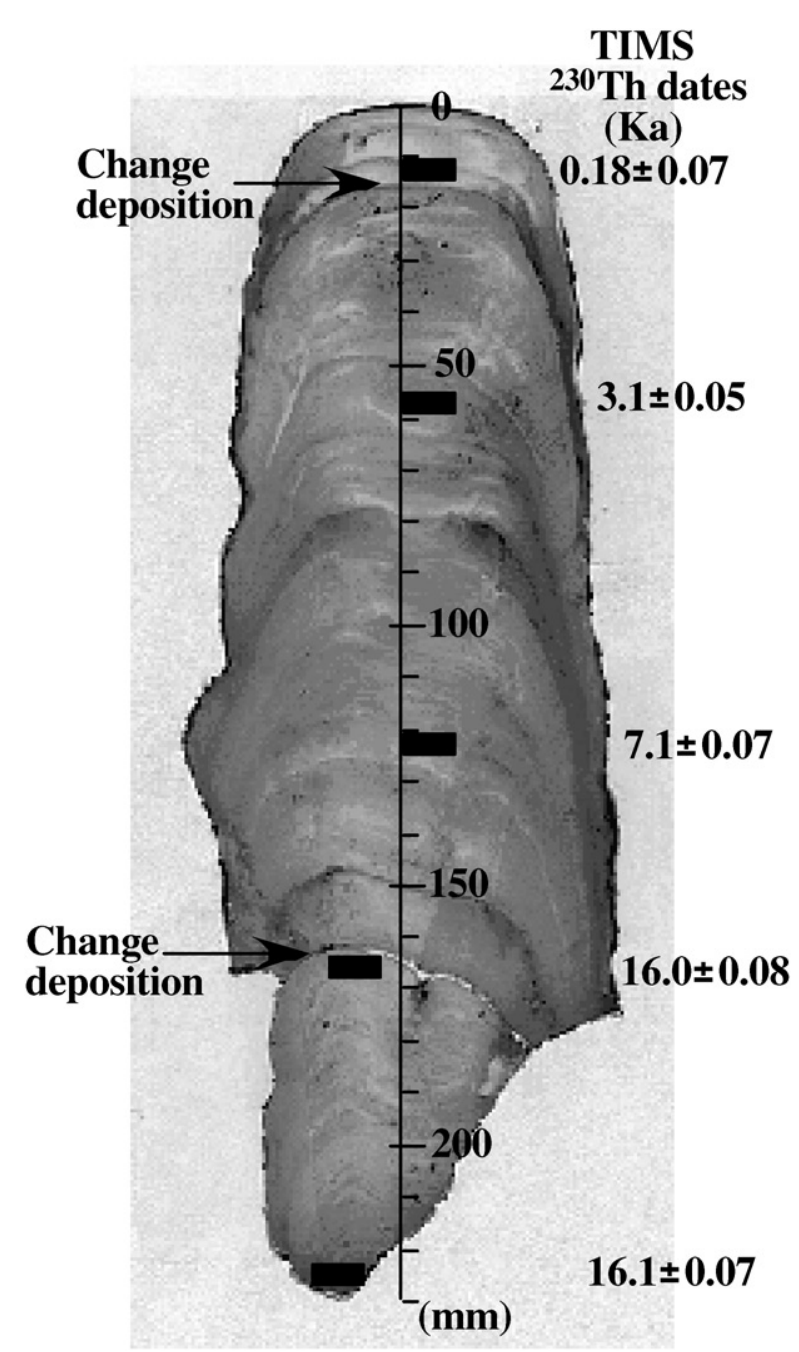

Fig. 3. A cross section of stalagmite SF-1 cut along the growth axis showing bands of growth layers.

isotopic analyses were made in a VG Prism II mass spectrometer equipped with an automated injection system of $\mathrm{CO}_{2}$ released from acidification of the carbonate samples. For about every 7 sample runs a working standard was analyzed. Based on the reproducibility of the standard runs analytical errors of $0.15 \%$ RMS for $\delta^{18} \mathrm{O}_{\mathrm{c}}$ and $0.1 \%$ RMS for $\delta^{13} \mathrm{C}_{\mathrm{c}}$ were estimated. Measurement precisions determined from six duplicate sample runs gave $0.1 \%$ RMS for $\delta^{18} \mathrm{O}_{\mathrm{c}}$ and $0.1 \%$ RMS for $\delta^{13} \mathrm{C}_{\mathrm{c}}$. The chronology of the records has been determined by TIMS ${ }^{230} \mathrm{Th} /{ }^{234} \mathrm{U}$ dating ${ }^{210} \mathrm{~Pb}$ dating and lamination counting. The latter two methods were applied to the $<150$-year part of the stalagmite sampled at $\sim 1$-year intervals for stable isotope analyses.

Lead-210 activities were determined via ${ }^{210} \mathrm{Po}$ by isotope-dilution alpha spectrometry using ${ }^{209} \mathrm{Po}$ as a yield tracer. The ${ }^{210} \mathrm{~Pb}$ dating showed exponential decrease of excess ${ }^{210} \mathrm{~Pb}$ activities with growth depth 

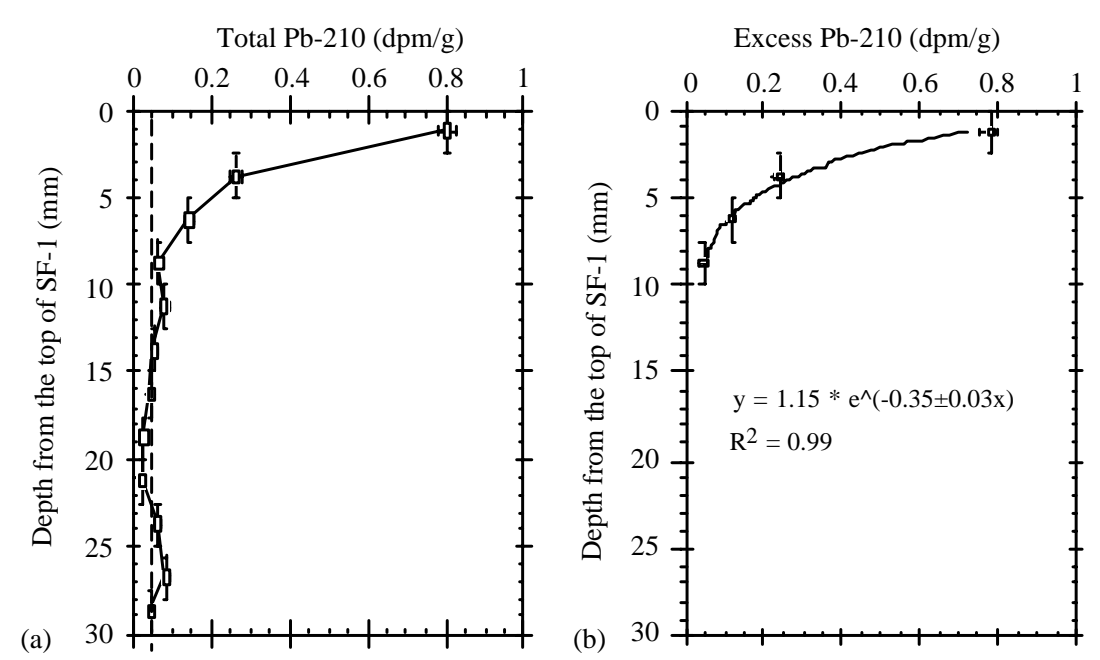

Fig. 4. (a) ${ }^{210} \mathrm{~Pb}$ dating of SF-1 showing the top $9 \mathrm{~mm}$ being younger than 100 years. The vertical dashed line represents the supported ${ }^{210} \mathrm{~Pb}$ activity level. (b) A growth rate of $0.089 \pm 0.007 \mathrm{~mm} / \mathrm{yr}$ for the top $14 \mathrm{~mm}$ is determined by excess ${ }^{210} \mathrm{~Pb}$ activities.

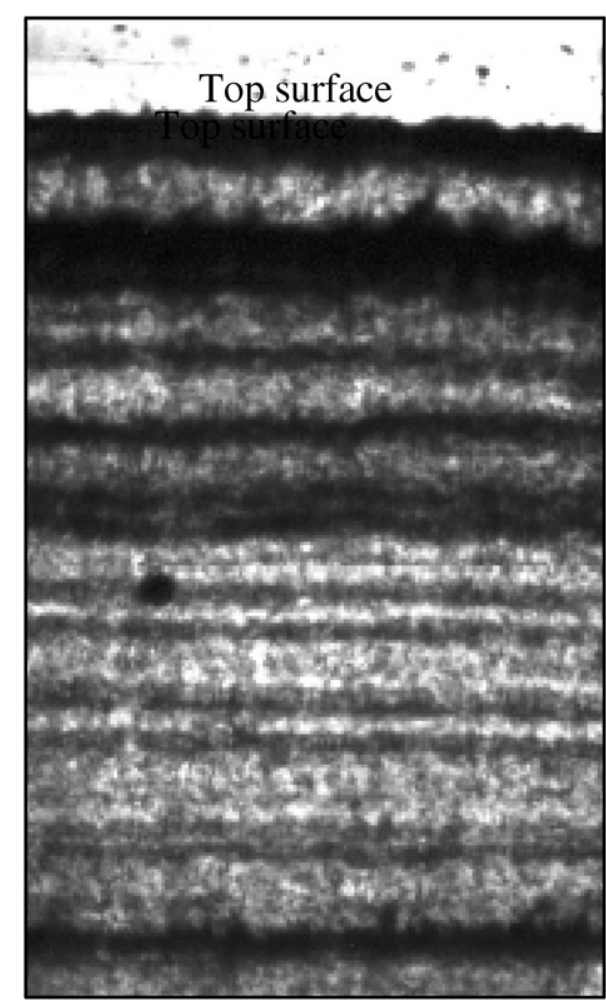

Fig. 5. Photomicrograph of growth laminations of the youngest part of SF-1.

indicating the top section of SF-1 to be younger than 100 years (Fig. 4). Transmission of visible light through a $\sim 0.5 \mathrm{~mm}$ thick thin section cut along the growth axis of SF-1 (Fig. 3) was used for lamination counting. Visual counting was performed under a microscope along several tracks with two countings done in each track and the use of a computer-programmed reference for band identification (Fig. 5). We take each couplet of the lamination to represent one year. A depth-age model (Paulsen, 2000) based on the results gave an average growth rate of $0.083 \mathrm{~mm} / \mathrm{yr}$ for the last 150 years in agreement with the mean rate of $0.089 \pm 0.007 \mathrm{~mm} / \mathrm{yr}$ determined from ${ }^{210} \mathrm{~Pb}$ (Fig. 4) and confirming the annual nature of the laminae ( $\mathrm{Li}$ et al., 2000). It should be noted however that growth rates of annual layers may vary as the thickness of growth bands depends on such factors as temperature dripping rate and $p \mathrm{CO}_{2}$ and $\mathrm{pH}$ of cave water. Therefore the use of average rates for assigning ages to individual layers as we shall adopt may introduce errors that are considerably larger than annual. For this reason the quoted chronology in the following discussion of results will be rounded to "5year" increments starting with 0 a (yr BP) as AD 1995 for the top layer of SF-1.

We have compared the instrumental precipitation records for the past 40 years in Xian $\left(34^{\circ} 18^{\prime} \mathrm{N} 108^{\circ} 54^{\prime} \mathrm{E}\right.$; $73 \mathrm{~km}$ north of Buddha Cave) and Ankang $\left(32^{\circ} 43^{\prime} \mathrm{N}\right.$ $109^{\circ} 02^{\prime} \mathrm{E} ; 105 \mathrm{~km}$ south of Buddha Cave) with the growth-band thickness and found no correlation between the two (Paulsen, 2000). Thus we were unable to support the hypothesis that growth layer thickness is directly related to wetness (Railsback et al., 1994; Shopov et al., 1994; Liu et al., 1997). Our lamination counting also showed an apparent deposition change to have occurred around $14 \mathrm{~mm}$ (ca $150 \mathrm{a}$ ) (Fig. 3). Below this depth the stalagmite grew so slowly as to defy lamination counting. TIMS ${ }^{230} \mathrm{Th} /{ }^{234} \mathrm{U}$ dating of SF-1 (Table 3) showed that the average growth rate prior to $150 \mathrm{a}$ was $0.0163 \mathrm{~mm} / \mathrm{yr}$ (Li et al., 2000). The dating work was done in the Isotope Laboratory of the University of Minnesota using a Finnigan-MAT 262RPQ mass spectrometer and the method of Edwards et al. (1987). 
Table 3

Analytical results of TIMS ${ }^{230} \mathrm{Th}$ age dating on stalagmite SF-1

\begin{tabular}{lcccccc}
\hline Sample & ${ }^{238} \mathrm{U}(\mathrm{ppb})$ & ${ }^{232} \mathrm{Th}(\mathrm{pg} / \mathrm{g})$ & ${ }^{230} \mathrm{Th} /{ }^{232} \mathrm{Th}$ activity & ${ }^{230} \mathrm{Th} /{ }^{238} \mathrm{U}$ activity & Uncorr. age (ka) & Corr. age (ka) \\
\hline SF-1-1 & $369.4 \pm 0.5$ & $4011.3 \pm 12$ & $21 \pm 0.2$ & $0.0758 \pm 0.0005$ & $6.20 \pm 0.04$ & $0.18 \pm 0.07$ \\
SF-1-2 & $268.2 \pm 0.5$ & $1147.2 \pm 9.4$ & $48 \pm 0.5$ & $0.0664 \pm 0.0005$ & $5.45 \pm 0.04$ & $3.1 \pm 0.05$ \\
SF-1-3 & $285.7 \pm 0.4$ & $313.5 \pm 5.1$ & $253 \pm 4.3$ & $0.0903 \pm 0.0004$ & $7.70 \pm 0.04$ & $7.1 \pm 0.07$ \\
SF-1-4 & $1542.4 \pm 2.5$ & $416.4 \pm 7$ & $1995 \pm 34$ & $0.1753 \pm 0.0008$ & $16.14 \pm 0.08$ & $16.0 \pm 0.08$ \\
SF-1-5 & $1605.8 \pm 2.3$ & $1203.1 \pm 11.4$ & $722 \pm 7$ & $0.1761 \pm 0.0005$ & $16.51 \pm 0.05$ & $16.1 \pm 0.07$ \\
\hline
\end{tabular}

The sampling depths are $1-1.5,5.5-6,12-12.5,16.2-16.8$ and $22-22.5 \mathrm{~cm}$. Sample weight ranges from 0.5604 to $0.9630 \mathrm{~g}$. The half-lives of ${ }^{232} \mathrm{Th}$ and ${ }^{238} \mathrm{U}$ used in age calculation are 75,674 and 245,205 years, respectively. The uncertainties quoted are $2 \sigma$ errors.

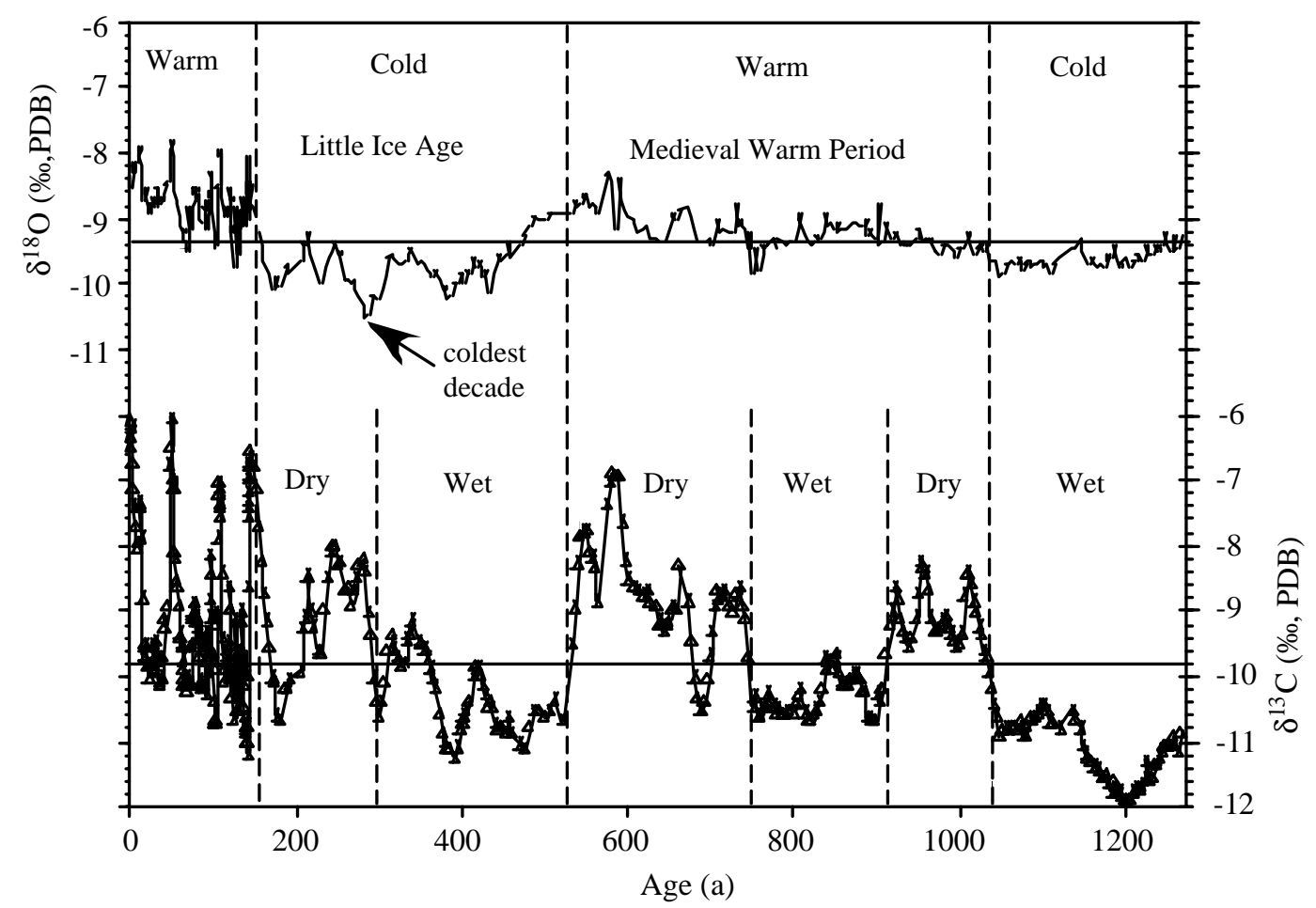

Fig. 6. Subdecadal isotopic records of stalagmite SF-1.

\section{Results and discussion}

Table 3 shows that the uppermost two samples contain relatively high ${ }^{232} \mathrm{Th}$ and low ${ }^{238} \mathrm{U}$ concentrations. In deriving their ages relatively large corrections for the initial ${ }^{230} \mathrm{Th}$ were required. The corrected dates show a fairly constant growth rate of $0.0163 \mathrm{~mm} / \mathrm{a}$ for the upper $16.5 \mathrm{~cm}$ (except the top $1.4 \mathrm{~cm}$ ). At this depth a depositional hiatus marks a change to a faster growth rate below as indicated by both the textural appearance of the specimen and the ${ }^{230} \mathrm{Th}$ dates (Fig. 3 and Table 3).

Fig. 6 shows the profiles of 478 pairs of $\delta^{13} C_{c}$ and $\delta^{18} \mathrm{O}_{\mathrm{c}}$ in SF-1 with subdecadal resolutions: about $1-\mathrm{yr}$ for the last 150 years and 3-4 yr resolution during 150 $1270 \mathrm{a}$. The climatic implications of the profiles will be examined using the criteria summarized in Tables 1 and 2. The two horizontal lines are average $\delta^{18} \mathrm{O}_{\mathrm{c}}$ and $\delta^{13} \mathrm{C}_{\mathrm{c}}$ values over the past 1270 years to denote respectively mean temperature and moisture conditions. Deviations from these averages indicate the presence in this record of climatic anomalies corresponding to the Medieval Warm (MW) Period (Lamb, 1965) the Little Ice Age (LIA) (Le Roy Ladurie \& Baulant, 1980); and the recent warming trend.

\subsection{Medieval warm period}

Largely due to a dearth of high-resolution climatic records our knowledge on the spatial extent duration and moisture characteristics of $\mathrm{MW}$ is incomplete (Crowley and North, 1991) and this has hampered our understanding of its cause or driving force. For instance the lack of high-resolution records worldwide prevents us from examining further the recent hypothesis calling for MW to represent a warm phase of a $1500 \pm 500$-year cycle related to thermohaline circulation 
(Bond et al., 1999; Clark et al., 1999; Broecker, 2001; deMenocal, 2001). In SF-1 we identify MW as the time interval from 1030 to 520 a (AD 965-1475) when $\delta^{18} \mathrm{O}_{\mathrm{c}}$ was heavier than the 1270-year average (except for a very brief span of 15 years between 760 and 745 a). This warm interval in central China lasted about 180 years longer than in Europe. The $\delta^{13} \mathrm{C}_{\mathrm{c}}$ record indicates changes in the moisture condition during MW. From 1030 to 910 a SF-1 had heavier $\delta^{13} \mathrm{C}_{\mathrm{c}}$ values suggesting that the climate was relatively dry and favored the growth of $\mathrm{C}_{4}$ plants in the region. In the ensuing period that lasted $\sim 165$ years (from 910 to $745 \mathrm{a}$ ) the $\delta^{13} \mathrm{C}_{\mathrm{c}}$ values reverted to lighter values as a result of an increased $\mathrm{C}_{3} / \mathrm{C}_{4}$ plant ratio under wetter climate. The last part of $\mathrm{MW}$ from 745 to 520 a was characterized by heavier $\delta^{13} \mathrm{C}_{\mathrm{c}}$ signifying a return to drier conditions with more $\mathrm{C}_{4}$ vegetation and/or decrease in vegetation density. Both $\delta^{18} \mathrm{O}_{\mathrm{c}}$ and $\delta^{13} \mathrm{C}_{\mathrm{c}}$ peaked hence the climate reached maximal warmth and dryness around 595 a (AD 1400). It is difficult to quantitatively isolate the temperature effect on $\delta^{18} \mathrm{O}_{\mathrm{c}}$. Graumlich (1993) used tree-ring widths to reconstruct paleotemperatures in the western US and showed high summer temperatures between AD 1100 and 1450 except for the period of AD $1300-1330$. If so the early 15 th-century warmth on two sides of the Pacific overlapped. Stine (1994, 1998) reported the occurrence of severe drought in California's Sierra Nevada during AD 900-1100 and 1210-1350. He coined the expression Medieval Climatic Anomaly (in lieu of Medieval Warm Period) to signify the far greater departure of precipitation than temperature from normal during medieval time. Though the general matching of the two dry intervals in Stine's records and ours can be called into attention we wish to emphasize the plausible century-long dry spells in eastern China during the Medieval Warm Period.

\subsection{Little ice age}

There is growing evidence for LIA as a global event (Lamb, 1982; Grove, 1988; Bradley and Jones, 1992; Mann, 1998; Broecker, 2001). Although it varies from region to region LIA is commonly referred to the period between AD 1500 and 1850 with two main cold stages of about centennial length occurring in the 17th and 19th centuries (Bradley and Jones, 1992). The onset of LIA is identified in our record at about 520 a (AD 1475) when $\delta^{18} \mathrm{O}_{\mathrm{c}}$ dropped rapidly below the 1270 -yr average (Fig. 6). The cold condition lasted until 150 a (AD $1845)$ with an earlier ( $~ 520-350$ a) wet period with $\delta^{13} \mathrm{C}_{\mathrm{c}}$ trending toward lighter values and later (350$150 \mathrm{a})$ turning to less moist (heavier $\delta^{13} \mathrm{C}_{\mathrm{c}}$ values). This wet-to-dry trend has also been noted in a stalagmite from the Shihua Cave near Beijing ( $\mathrm{Ku}$ and $\mathrm{Li}, 1998$ ). The $\delta^{18} \mathrm{O}_{\mathrm{c}}$ record of SF-1 suggests that LIA can be divided into three periods: $450-355$ a (AD 1545-1640)
320-250 a (AD 1675-1745) and 205-170 a (AD 17901825). These periods correspond to the three intervals when Mongolia was $\sim 1-2^{\circ} \mathrm{C}$ colder than the present according to the tree-ring record (Fig. 1; Jacoby et al., 1996). The coldest time centered around 295-275 a (AD 1700-1720) consistent with the recorded freezing/thawing history of rivers and lakes in central and southern China showing that 1711-1720 was the coldest decade over the last 480 years (Bradley, 1999). Ice core oxygen isotope data from the Dunde Ice Cap (Fig. 1) in northwestern China point to a similar cold trend for the period of AD 1560-1660 (Mosley-Thompson et al., 1993). However the latest two LIA cold stages as well as the Medieval Warm Period were not recorded at Dunde. It appears that Buddha Cave and Dunde Ice Cap being $\sim 1100 \mathrm{~km}$ apart could belong to different climate regimes.

Comparing the $\delta^{18} \mathrm{O}_{\mathrm{c}}$ record of SF-1 with the records of Mongolian tree rings and Shihua Cave in NE China indicates that LIA ended in central China approximately 50 years earlier than areas to the north i.e. LIA in Mongolia and NE China lasted until $\sim$ AD 1900 as opposed to $\sim$ AD 1850 for central China. The offset is not likely the result of dating uncertainties considering the fact that chronology for the younger parts of SF-1 and for the Mongolian tree ring record should be accurate to within a decade if not a few years.

It should be mentioned that cold temperatures were also registered by tree ring data in western China (Fig. 1; Zhang and Crowley, 1989) and that Chinese historical records show relatively frequent occurrences of droughts dust storms and floods during LIA (Zhang and Crowley, 1989). While humidity may differ over relatively small spatial scales cold temperatures could well prevail over a very broad region during the Little Ice Age.

\subsection{Global warming trend}

Relative to the earlier $(150-1270$ a) records the last 150 -year part of the SF-1 records with approximately annual resolutions has two distinct features: (1) a good correlation between $\delta^{18} \mathrm{O}_{\mathrm{c}}$ and $\delta^{13} \mathrm{C}_{\mathrm{c}}\left(R^{2}=0.67\right)$ and (2) high-frequency large variations in $\delta^{18} \mathrm{O}_{\mathrm{c}}$ and $\delta^{13} \mathrm{C}_{\mathrm{c}}$ (Fig. 6). For example $\delta^{13} \mathrm{C}_{\mathrm{c}}$ increased from $-10.1 \%$ in 1940 to $-5.5 \%$ in $\mathrm{AD} 1955$ and then decreased to $-10.1 \%$ in $\mathrm{AD} 1965$. In the same period $\delta^{18} \mathrm{O}_{\mathrm{c}}$ underwent a large change of $2 \%$. Inasmuch as natural and human-induced changes in regional vegetation generally occur on time scales longer than decades vegetation alteration cannot be the main cause for the observed $\delta^{13} \mathrm{C}_{\mathrm{c}}$ variations. Rather the variations most likely reflect a change of water residence time in the vadose zone above the cave. During wet years reduced residence time would lead to less dissolution of the limestone bedrock and higher cave-water dripping rates which would suppress the escape of $\mathrm{CO}_{2}$ from solution; both 
processes would result in lighter $\delta^{13} \mathrm{C}$ values in the stalagmite calcite. The wet years should lead to a lowering of the $\delta^{18} \mathrm{O}_{\mathrm{c}}$ as well (note also that the frequency and amplitude of its variation cannot be attributed to temperature changes). Thus local precipitation changes were mainly responsible for the observed subdecadal time-scale variations of both $\delta^{18} \mathrm{O}_{\mathrm{c}}$ and $\delta^{13} \mathrm{C}_{\mathrm{c}}$ and their co-variance during the past 150 years. The prominent $\delta^{18} \mathrm{O}_{\mathrm{c}}$ and $\delta^{13} \mathrm{C}_{\mathrm{c}}$ peaks centered around AD 1835, 1878 and 1955 indicate drought conditions during these years. The 1877-1878 drought had caused widespread famine and the death of 9-13 million people in northern China (Nicholls, 1991). Although the $\delta^{13} C_{c}$ record during the past 150 years mainly reflects changes in water residence time the overall $\delta^{13} \mathrm{C}_{\mathrm{c}}$ trend during this period parallels the overall $\delta^{18} \mathrm{O}$ trend showing the linkage between $\delta^{13} \mathrm{C}_{\mathrm{c}}$ and vegetation on longer terms. It is also interesting to note that an increase of $\delta^{13} \mathrm{C}_{\mathrm{c}}$ in SF1has occurred following the opening of Buddha Cave to the public since 1980 s to reflect changes in the humidity and ventilation of the cave (Fig. 6).

On the whole $\delta^{18} \mathrm{O}_{\mathrm{c}}$ for the past 150 years was heavier than the 1270-year average. Furthermore superimposed on its subdecadal variations is a gradual increase of $\sim 1 \%$ o towards the modern - an increase that is best explained as reflecting the global warming trend that began as early as in the late 1800s (Crowley, 2000). This trend has been detected in other speleothem records from eastern China (Li et al., 1998) in tree ring records from western China (Kang et al., 1997) and Mongolia (Jacoby et al., 1996) and in ice core records from Tibet (Thompson et al., 2000). Although the ultimate cause(s) for the trend remains unresolved a good part could be contributed from anthropogenic forcing (e.g. Crowley, 2000).

\subsection{Cycles in the records}

In addition to MW and LIA several shorter cycles can be seen in the SF-1 records. We have performed spectral analyses separately on the 150-year and 1270-year records. The resultant power spectra are shown in Fig. 7 with the major periodicities listed in Table 4. For the 150-year high-resolution records both $\delta^{18} \mathrm{O}_{\mathrm{c}}$ and $\delta^{13} C_{c}$ reveal 11- and 9.6-year cycles whereas in the 1270 year low-resolution records the 33-year cycle is the only significant periodicity found.
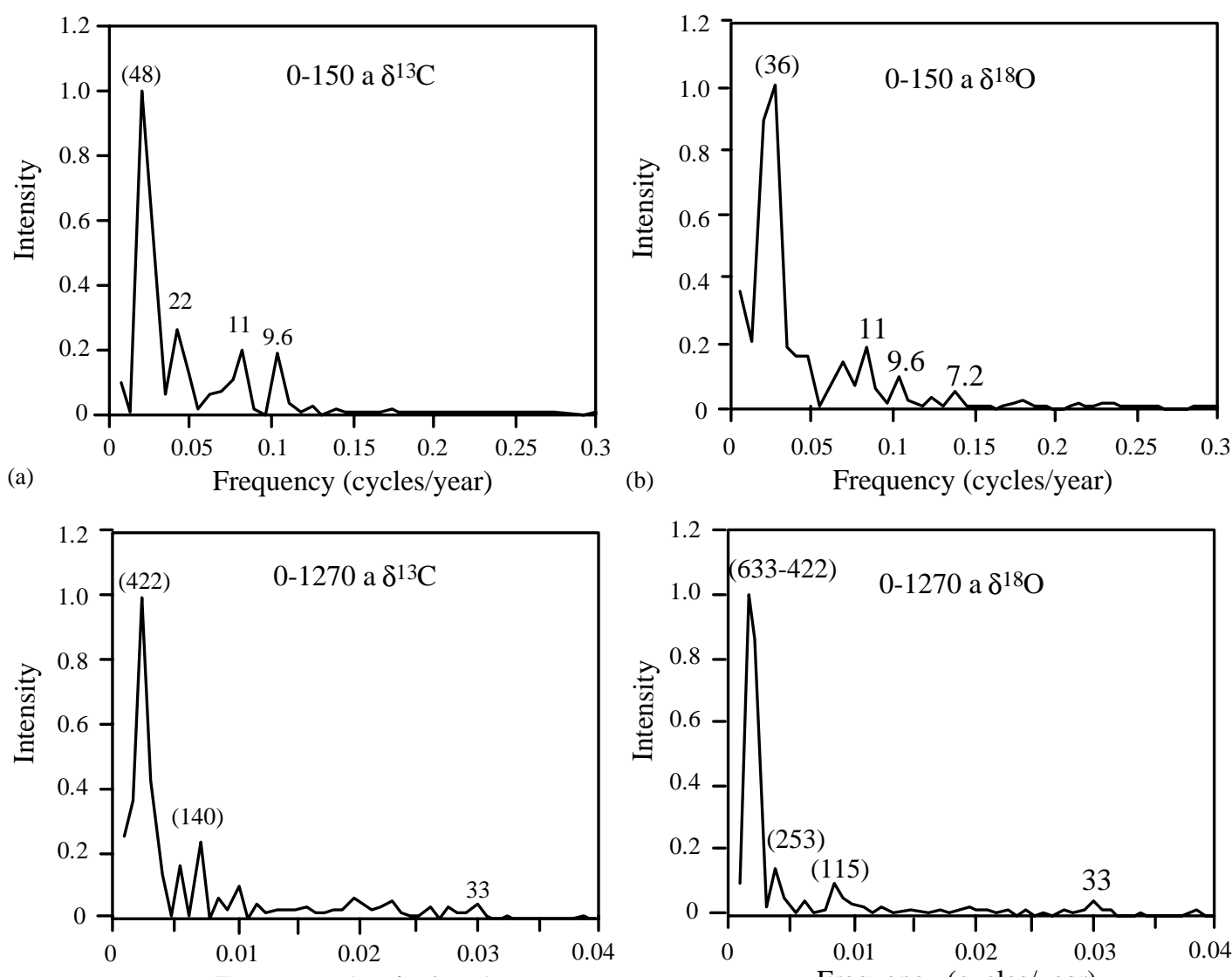

(c)

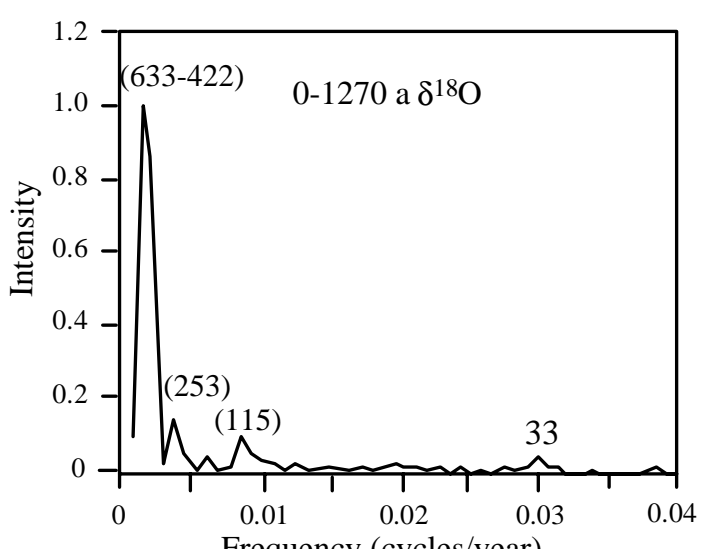

(d)

Frequency (cycles/year)

Fig. 7. Power spectra for (a) the $0-150$ year $\delta^{13} \mathrm{C}_{\mathrm{c}}$ record; (b) the $0-150$ year $\delta^{18} \mathrm{O}_{\mathrm{c}}$ record; (c) the $0-1270$ year $\delta^{13} \mathrm{C}_{\mathrm{c}}$ record; (d) the $0-1270$ year $\delta^{18} \mathrm{O}_{\mathrm{c}}$ record. Periods in parentheses are uncertain because the record is not long enough. 
Table 4

Periodicities identified by spectral analyses. All periodicities identified have a confidence level of $95 \%$

\begin{tabular}{lll}
\hline Isotopic signal & Period & Cycles \\
\hline$\delta^{13} \mathrm{C}$ & $0-150$ year record & $22,11^{\mathrm{a}}$ and $9.6^{\mathrm{a}}$ years \\
& $0-1270$ year record & $33^{\mathrm{a}}$ years \\
$\delta^{13} \mathrm{O}$ & $0-150$ year record & $14.4,11^{\mathrm{a}}, 9.6^{\mathrm{a}}$ and 7.2 years \\
& $0-1270$ year record & $33^{\mathrm{a}}$ years \\
\hline
\end{tabular}

${ }^{\text {a }}$ Period shown in both $\delta^{13} \mathrm{C}$ and $\delta^{18} \mathrm{O}$.

The 22-year cycle (and its harmonic of 11 years) has been identified in the historical data on drought and flooding in the central part of the Yangtze River $(\mathrm{Ku}$ and $\mathrm{Li}, 1998$ ). The 22- 11- and 9.6-year cycles have been found in climate records throughout the world and they reflect features of Sunspots or the Lunar orbit (Bryant, 1997). The 11- and 9.6-year cycles present in both the $\delta^{18} \mathrm{O}_{\mathrm{c}}$ and $\delta^{13} \mathrm{C}_{\mathrm{c}}$ records (Table 3) thus indicate that precipitation variability in the Buddha Cave area may be related to solar irradiance. As much of the precipitation is brought into the area by the Eastern Asia Summer Monsoon it would be important to study in the future the possible cyclic nature of the summer monsoon strength.

The 33-year cycle has also been found in a Shihua Cave stalagmite from $\mathrm{NE}$ China studied by $\mathrm{Ku}$ and $\mathrm{Li}$ (1998) who mentioned its match with the 35-year cycle recognized in Europe and central Asia by Brückner as early as 1890. Bradley (1999) noted a 36-year cyclicity from historical data of eastern Yangtze River Basin and southwestern China and related it to the large synopticscale pressure anomalies over eastern Asia and adjacent equatorial regions. Are these 33 to 36 -year cycles in effect one of the same and if so what causes the possible teleconnection? These are questions to be answered.

The presence of the 7.2-year cycle (and its multiple 14.4-year cycle) in the 150 -year $\delta^{18} \mathrm{O}_{c}$ record supports the finding by Hughes et al. (1994) of a quasi-periodic 7.2-year precipitation cycle recorded by tree rings in the Qin Ling Mountains (where Buddha Cave is located). The in-phase relationship between the two records also lends credence to our interpretation of the $\delta^{18} \mathrm{O}_{\mathrm{c}}$ signals discussed above.

\section{Conclusions}

High-resolution records of $\delta^{13} \mathrm{C}_{\mathrm{c}}$ and $\delta^{18} \mathrm{O}_{\mathrm{c}}$ in stalagmite SF-1 from Buddha Cave are used to infer changes in climate in central China for the last 1270 years in terms of warmer, colder, wetter and drier conditions. An increase in $\delta^{13} \mathrm{C}_{\mathrm{c}}$ values serves as a proxy for a drier and/or warmer climate, whereas a decrease in $\delta^{13} \mathrm{C}_{\mathrm{c}}$ values infers a wetter and/or colder climate. Short- term $(<10$ years $)$ variations in $\delta^{18} \mathrm{O}_{\mathrm{c}}$ reflect changes in precipitation amounts, whereas longer-term ( $>50$ years) $\delta^{18} \mathrm{O}_{\mathrm{c}}$ variations indicate changes in air temperature.

Identified in the records are climatic anomalies known as Medieval Warm Period, Little Ice Age and 20thcentury warmth. Thus our work adds to the growing evidence for the global extent of these events. Also shown in SF-1 is the cyclic nature of the climate that has been noted elsewhere in China and other parts of the world. The prominent cyclicities found include those of 33, 22, 11, 9.6, and 7.2 years. The unprecedented fine resolution of the records allows for calibration/validation with historically documented climatic shifts in China, such as the coldest spell in the early 18 th century ca 295-275a. Agreements with tree-ring and ice-core studies, as well as with isotopic records of speleothems from other parts of China, reinforce our confidence in reading climatic messages from the isotopic composition of cave deposits in general and speleothem SF-1 in particular.

\section{Acknowledgements}

This research was supported by National Science Foundation grant ATM-9818407. The stable isotope measurements were made in the laboratory of Prof. Lowell D. Stott at USC, and the TIMS U-series dating was carried out in the laboratory of Prof. R. Lawrence Edwards at University of Minnesota, to whom we are most grateful. The helpful comments of Prof. Joyce Lundberg at Carleton University and another anonymous reviewer are much appreciated. We thank Dr. Fei Wang (Institute of Geology, China Seismological Bureau) for his help during the fieldwork in 1996.

\section{References}

Baker, A., Smart, P.L., Edwards, R.L., Farrant, A., 1993. Annual growth banding in a cave stalagmite. Nature 304, 518-520.

Baker, A., Ito, E., Smart, P.L., McEwan, R.F., 1997. Elevated and variable values of ${ }^{13} \mathrm{C}$ in speleothems in a British cave system. Chemical Geology 136, 263-270.

Baker, R.G., González, L.A., Raymo, M., Bettis III, E.A., Reagan, M.K., Dorale, J.A., 1998. Comparison of multiple proxy records of Holocene environments in the Midwestern United States. Geology 26, 1131-1134.

Bar-Matthews, M., Ayalon, A., Matthews, A., Sass, E., Halicz, L., 1996. Carbon and oxygen isotope study of the active watercarbonate system in a karstic Mediterranean cave: implications for paleoclimate research in semiarid regions. Geochimica et Cosmochimica Acta 60, 337-347.

Bar-Matthews, M., Ayalon, A., Kaufman, A., 1997. Late Quaternary paleoclimate in the eastern Mediterranean region from stable isotope analysis of speleothems at Soreq Cave, Israel. Quaternary Research 47, 155-168.

Bar-Matthews, M., Ayalon, A., Kaufman, A., Wasserburg, G.J., 1999. The eastern Mediterranean paleoclimate as a reflection of regional 
events: Soreq Cave, Israel. Earth and Planetary Science Letters 166, 85-95.

Baskaran, M., Iliffe, T.M., 1993. Age determination of recent cave deposits using excess ${ }^{210} \mathrm{~Pb}$ - a new technique. Geophysical Research Letters 20, 603-606.

Bond, G.C., Showers, W., Elliot, M., Evans, M., Lotti, R., Hajdas, I., Bonani, G., Johnson, S., 1999. The North Atlantics 1-2 kyr climate rhythm: Relation to Heinrich events, Dansgaard/Oeschger cycles and the Little Ice Age. In: Clark, P.U., Webb, R.S., Keigwin, L.D. (Eds.), Mechanisms of Global Climate Change at Millennial Time Scales, Geophysical Monograph Series 112. American Geophysical Union, Washington, DC, pp. 35-58.

Bradley, R.S., 1999. Paleclimatology, Reconstructing Climates of the Quaternary, 2nd Edition. Academic Press, New York.

Bradley, R.S., Jones, P.D., 1992. When was the "Little Ice Age"? In: Mikami, T. (Ed.), Proceedings of the International Symposium on the Little Ice Age Climate. Department of Geography, Tokyo Metropolitan University, Tokyo, pp. 1-4.

Broecker, W.S., 2001. Was the medieval warm period global. Science 291, 1497-1499.

Bryant, E., 1997. Climate Process and Change. Cambridge University Press, Cambridge.

Burns, S.J., Matter, A., Frank, N., Mangini, A., 1998. Speleothem-based paleoclimate record from northern Oman. Geology 26, 499-502.

Cerling, T.E., 1984. The stable isotopic composition of soil carbonate and its relationship to climate. Earth and Planetary Science Letters 71, 229-240.

Cerling, T.E., Quade, J., Wand, Y., Bowman, J.R., 1989. Carbon isotopes in soils and paleosols as ecology and paleoecology indicators. Nature 341, 138-139.

Clark, P.U., Webb, R.S., Keigwin, L.D., 1999. Mechanisms of global climate change at millennial time scales. American Geophysical Union, Geophysical Monograph Series 112, 394.

Crowley, T.J., 2000. Causes of climate change over the past 1000 years. Science 289, 270-277.

Crowley, T.J., North, G.R., 1991. Paleoclimatology. Oxford Monographs on geology and geophysics, Vol. 18. Oxford University Press, New York, 339pp.

Dansgaard, W., 1964. Stable isotopes in precipitation. Tellus 16, 436468.

Denniston, R.F., González, L.A., Asmerom, Y., Baker, R.G., Reagan, M.K., Bettis III, E.A., 1999. Evidence for increased cool season moisture during the middle Holocene. Geology 27, 815-818.

deMenocal, P.B., 2001. Cultural responses to climate change during the Late Holocene. Science 292, 667-673.

Desmarchelier, J.M, Goede, A., Ayliffe, L.K., McCulloch, M.T., Moriarty, K., 2000. Stable isotope record and its paleoenvironmental interpretation for a late Middle Pleistocene speleothem from Victoria Fossil Cave, Naracoorte, South Australia. Quaternary Science Reviews 19, 763-774.

Dorale, J.A., González, L.A., Reagan, M.K., Pickett, D.A., Murrell, M.T., Baker, R.G., 1992. A high-resolution record of Holocene climate change in speleothem calcite from Cold Water Cave, Northeast Iowa. Science 258, 1626-1630.

Dorale, J.A., Edwards, R.L., Ito, E., González, L., 1998. Climate and vegetation history of the midcontinent from 75 to $25 \mathrm{ka}$ : a speleothem record from Crevice Cave, Missouri, 25. Science 282, 1871-1873.

Dulinski, M., Rozanski, K., 1990. Formation of ${ }^{13} \mathrm{C} /{ }^{12} \mathrm{C}$ isotope ratios in speleothems: a semi-dynamic model. Radiocarbon 32, 7-16.

Edwards, R.L., Chen, J.H., Wasserburg, G.J., 1987. ${ }^{238} \mathrm{U}_{-}{ }^{234} \mathrm{U}^{230} \mathrm{Th}^{2}{ }^{232} \mathrm{Th}$ systematics and precise measurement of time over the past 500,000 years. Earth and Planetary Science Letters $81,175-192$.
Epstein, S., Buchsbaum,, R., Lowenstam, H.A., Urey, H.C., 1953. Revised carbonate-water isotopic temperature scale. Bulletin of the Geological Society of America 64, 1315-1326.

Gascoyne, M., 1992. Paleoclimate determination from cave calcite deposits. Quaternary Science Reviews 11, 609-632.

Graumlich, L.J., 1993. A 1000-year record of temperature and precipitation in the Sierra Nevada. Quaternary Research 39, 249-255.

Grove, L.M., 1988. The Little Ice Age. Methuen, New York.

Hellstrom, J., McCulloch, M., Stone, J., 1998. A detailed 31,000-year record of climate and vegetation change from the isotope geochemistry of two New Zealand speleothems. Quaternary Research 50, 167-178.

Hendy, C.H., 1971. The isotopic geochemistry of speleothems-I. The calculation of the effects of different modes of formation on the isotopic composition of speleothems and their applicability as paleoclimate indicators. Geochimica et Cosmochimica Acta 35, 801-824.

Hendy, C.H., Wilson, A.T., 1968. Palaeoclimatic data from speleothems. Nature 219, 48-51.

Hoefs, J., 1997. Stable Isotope Geochemistry. Springer, Berlin, Heidelberg.

Holmgren, K., Karlén, W., Shaw, P.A., 1995. Paleoclimatic significance of the stable isotopic composition and petrology of a Late Pleistocene stalagmite from Botswana. Quaternary Research 43, 320-328

Hughes, M.K., Xiangding, W., Xuemei, S., Garfin, G.M., 1994. A preliminary reconstruction of rainfall in north-central China since AD 1600 from tree-ring density and width. Quaternary Research 42, 88-99.

Jacoby, G.C., D'Arrigo, R.D., Davaajamts, T., 1996. Mongolian tree rings and 20th-century warming. Science 273, 771-773.

Kang, X.-C., Graumlich, L.J., Sheppard, P., 1997. The last 1835 years climate changes inferred from tree ring records in Dulan region, Qinghai, China. Quaternary Science 70-75 (in Chinese).

Kaufman, A., Wasserburg, G.J., Porcelli, D., Bar-Matthews, M., Ayalon, A., Halicz, L., 1998. U-Th isotope systematics from the Soreq Cave, Israel and climatic correlations. Earth and Planetary Science Letters 156, 141-155.

Ku, T.-L., Li, H.-C., 1998. Speleothems as high-resolution paleoenvironment archives: records from northeastern China. Proceedings of the Indian Academy of Sciences. Earth and Planetary Sciences 107, $321-330$

Ku, T.-L., Li, H.-C., Stott, L.D., 1998. Decadal climatic reconstruction from stable isotope records of speleothem in Shihua Cave, China: A summer monsoon domain. In: Wilson, R.C., Tharp, V.L. (Eds.), Proceedings of 14th Annual Pacific Climate (PACLIM) Workshop, April 6-9, 1997. Interagency Ecological Program, Technical Report 57, California Department of Water Resources, pp. 1-14.

Lamb, H.H., 1965. The early medieval warm epoch and its sequel. Palaeogeography, Palaeoclimatology, Palaeoecology 1, 13-37.

Lamb, H.H., 1982. Climate, History and the Modern World. Methuen, London, 387pp.

Lauritzen, S.E., 1995. High-resolution paleotemperature proxy record for the last interglaciation based on Norwegian speleothems. Quaternary Research 43, 133-146.

Li, W.-X., Lundberg, J., Dickin, A.P., Ford, D.C., Schwarcz, H.P., McNutt, R., Williams, D., 1989. High precision mass spectrometric U-series dating of cave deposits and implications for paleoclimate studies. Nature 339, 534-536.

Li, H.-C., Ku, T.-L., Stott, L.D., Chen, W.-J., 1998. Applications of interannual-resolution stable isotope records of speleothem: Climatic changes in Beijing and Tianjin, China during the past 500 years - the $\delta^{18} \mathrm{O}$ record. Science in China (Series D) 41, 362-368. 
Li, H.-C., Ku, T.-L., Paulsen, D.E., Wang, F., Chen, W.-J., Ying, G.-M., Cheng, H., Edwards, R.L., 2000. Paleoclimatic and paleomonsoonal variations in central china recorded by stable isotopic records of stalagmites from Buddha Cave, South Shaanxi. Seismology and Geology 22, 63-78 (In Chinese).

Liu, T.-S., Tan, M., Qin, X.-G., Zhao, S.-S., Li, T.-Y., Lu, J.-B., Zhang, D.-E., 1997. Discovery of microbedding in speleothems in China and its significance in the study of global change. Quaternary Sciences 1, 41-53 (in Chinese).

Le Roy Ladurie, E., Baulant, M., 1980. Grape harvests from the fifteenth through the nineteenth centuries. Inderdisc. History 10 , 839-849.

Mann, M.E., Bradley, R.S., Hughes, M.K., 1998. Global-scale temperature patterns and climate forcing over the past six centuries. Nature 392, 779-787.

McDermott, F., Frisia, S., Huang, Y., Longinelli, A., Spiro, B., Heaton, T.H.E., Hawkesworth, C.J., Borsato, A., Keppens, E., Fairchild, I.J., Van der Borg, K., Verheyden, S., Selmo, E., 1999. Holocene climate variability in Europe: evidence from $\delta^{18} \mathrm{O}$, textural and extension-rate variations in three speleothems. Quaternary Science Reviews 18, 1021-1038.

Mosley-Thompson, E., Thompson, L.G., Dai, J., Davis, M., Lin, P.N., 1993. Climate of the last 500 years: high resolution ice core records. Quaternary Science Reviews 12, 419-430.

Nicholls, N., 1991. Teleconnections and health. In: Glantz, M. H., Katz, R. W. (Eds.), Teleconnections Linking Worldwide Climate Anomalies. Cambridge University Press, Cambridge, pp. 493-510.

Njitchoua, R., Sigha-Nkamdjou, L., Dever, L., Marlin, C., Sighomnou, D., Nia, P., 1999. Variations of the stable isotopic compositions of rainfall events from the Cameroon rain forest, Central Africa. Journal of Hydrology 223, 17-26.

O’Neil, J.R., Clayton, R.N., Mayeda, T.K., 1969. Oxygen isotope fractionation in divalent metal carbonates. Journal of Chemical Physics 51, 5547-5558.

Paulsen, D.E., 2000. Multi-proxy studies of climate variability in Central China: Subdecadal to Centennial records in stalagmite from Buddha Cave. M.S. thesis, University of Southern California.

Railsback, L.B., Brook, G.A., Chen, J., Kalin, R., Fleisher, C.J., 1994. Environmental controls on the petrology of a Late Holocene speleothem from Botswana with annual layers of aragonite and calcite. Journal of Sedimentary Research 64, 147-155.

Repinski, P., Holmgren, K., Lauritzen, S.E., Lee-Thorp, J.A., 1999. A late Holocene climate record from a stalagmite, Cold Air Cave, Northern Province, South Africa. Palaeogeography, Palaeoclimatology, Palaeoecology 150, 269-277.

Rindsberger, M., Margaritz, M., Carmi, I., Gilad, D., 1983. The relation between air mass trajectories and the water isotope composition of rain in the Mediterranean Sea area. Geophysical Research Letters 10, 43-46.

Rozanski, K., Arzguas-Araguas, L., Gonfiantini, R., 1993. Isotopic patterns in modern global precipitation, In: Swart, P.K., et al., Climate Change in Continental Isotopic Records, American Geophysical Union, Monograph, Vol. 78, pp. 1-36.

Schleser, G.H., Helle, G., Lucke, A., Vos, H., 1999. Isotope signals as climate proxies: the role of transfer functions in the study of terrestrial archives. Quaternary Science Review 18, 927-943.

Shopov, Y.Y., Ford, D.C., Schwarcz, H.P., 1994. Luminescent microbanding in speleothems: high resolution chronology and paleoclimate. Geology 22, 407-410.

Stine, S., 1994. Extreme and persistent drought in California and Patagonia during mediaeval time. Nature 369, 546-549.

Stine, S., 1998. Medieval climatic anomaly in the Americas. In: Issar, A.S., Brown, N. (Eds.), Water, Environment and Society in Times of Climatic Change. Kluwer Academic Publishers, Dordrecht, pp. 43-67,

Thompson, L.G., Yao, T., Mosley-Thompson, E., Davis, M.E., Henderson, K.A., Lin, P.-N., 2000. A high-resolution millennial record of the south Asian monsoon from Himalayan ice cores. Science 289, 1916-1919.

Zhang, J.-C., Crowley, T.J., 1989. Historical climate records in China and reconstruction of past climates. Journal of Climate 2, 833-849. 